\title{
REKAYASA TEKNIK SIPIL
}

Media Publikasi Karya Ilmiah di Bidang Teknik Sipil

Volume 4, Nomer 2.

Desember 2019

\section{DAFTAR ISI}

1. Pengaruh Gaya Kepemimpinan Terhadap Budaya K3 yang Dimoderasi Tingkat Pendidikan dan Pengalaman Kerja pada Proyek Konstruksi di Surabaya Jenny Caroline, Feri Harianto, Rochman Pasik H

2. Studi Eksperimental Penambahan Serbuk Arang Kayu Dengan Kadar 10\% Terhadap Filler Semen Pada Campuran Perkerasan AC - WC Kurnia Hadi Putra, Mutiara Fidausi

3. Analisis Penerapan Sistem Manajemen K3 dan Kelengkapan Fasilitas K3 Pada Proyek Konstruksi Gedung Di Surabaya Arizal Firmansyah, Priyono, Feri Harianto

4. Analisis Pada Pekerjaan Galian Untuk Mencari Produktivitas Dan Kombinasi Alat Berat Di Proyek Pembangunan Refinery Di Pt. Salim Ivomas Pratama, Tbk.

Mauliddiyah Ainurrizki, Siti Choiriyah, Theresia MCA

5. Analisis Kinerja Operasional dan Kualitas Pelayanan PO. Mutiara Indah Murni dan PO. Widji Lestari pada Trayek Surabaya-Tuban Amrita Winaya, Theresia MCA, Bimanda Maryudi

6. Analisis Percepatan Durasi Terhadap Pekerjaan Proyek Konstruksi Time Cost Trade Off Method ( Studi Kasus : Pembangunan Gedung Dinas Perdagangan Dan Perindustrian Kabupaten Sampang )

Dedy Asmaroni, Ach Fendi 